\title{
KEWENANGAN KOMISI PEMBERANTAS KORUPSI DALAM MELAKUKAN PENUNTUTAN MONEY LAUNDERING
}

\author{
Roni Efendi \\ Fakultas Syariah IAIN Batusangkar \\ J1. Jenederal Sudirman No. 137, Lima Kaum Batusangkar \\ e-mail: rhonieeffendy@gmail.com
}

\begin{abstract}
The tackling of money laundering through the criminal Justice System has not been debatable as long as it is handled by sub-systems in the criminal justice system such as the police and prosecutors since they have been bestowed a clear mandate in law. That raised a question, what about Corruption Eradication Commission or KPK? In Article 6 letter C Act no.30 of 2002 on the Corruption Eradication Commission (Law of KPK) explicitly and clearly revealed that the KPK has a duty to conduct the initial investigation, investigation and prosecution of corruption. That article also did not provide the further explanation. For that reason, the authority of KPK in conducting initial investigation, investigation and prosecution is only regarding the criminal act of corruption. In several corruption cases settling, KPK also often tried to apprehend the perpetrators through the law of prevention and Eradication of Money Laundering Crime. Many People criticized KPK but some gave the appreciation on KPK's efforts in asset recovery. That was also addressed to KPK on its' authority in investigating and prosecuting TPPU. In the case of No. 39/Pid.Sus/ TPK/2013/PN.Jkt.Pst with the accused Abmad Fathanah, Joko Subagion and I made Hendra as 2 (two) members of the judges' panel stated dissenting opinion. It declared that KPK has the authority to investigate TPU but it is only concerning with the wealth which is suspected from a criminal act of corruption. Actually, the authority to persecute TPPU is on the general attorney. Meanwhile, persecutors of KPK does not have the right to file the indicment and demand of the TPPU. Therefore, the indictment related to money laundering should be declared unacceptable. It brings the writer's unrest on the criminal law enforcement's practice. It is especially in the eradication of money laundering since it is supposed that law enforcement does no provide justice for justicia belene, certainty and expediency in asset recovery.
\end{abstract}

Kata kunci: money laundering, penuntutan, komisi pemberantasan korupsi.

\section{PENDAHULUAN}

$\mathcal{M}$ oney laundering atau tindak pidana pencucian uang merupakan transnational organized crime, sehingga dalam pemberantasannya seringkali berkaitan dengan yurisdiksi negara lain, dan memerlukan kerjasama internasional. Dalam kaitan dengan kerjasama memberantas money laundering, sejak bulan Juni 2001 Indonesia bersama sejumlah negara lain dinilai kurang kooperatif dan dimasukkan ke dalam daftar Non Cooperative Countries and Territories oleh Financial Action Task Force on Money Laundering (FATF) suatu gugus tugas yang beranggotakan 31 negara dan 2 organisasi regional, (FATF, Press Release 3 Oktober 2003). Walaupun Indonesia tidak pernah menjadi anggota FATF, 
namun Indonesia menjadi anggota Asia/Pacific Group on Money Laundering (APG) sejak tahun 2000. APG didirikan pada tahun 1998 dengan anggota sebanyak 26 negara dan salah satunya adalah Indonesia, (Yunus Husein, 2004: 1).

Tindak pidana pencucian uang (TPPU) merupakan kejahatan yang dapat merusak sendi-sendi kehidupan bermasyarakat, berbangsa dan bernegara. Hal ini tidak terlepas dari dampak negatif tindak pidana pencucian uang antara lain dapat meningkatkan motivasi seseorang atau organisasi kejahatan untuk mengembangkan kejahatannya yang pada gilirannya dapat pula menciptakan kemiskinan dan kebodohan, merusak struktur keuangan dan perekonomian serta terganggunya stabilitas pemerintahan (Naskah Akademik Rancangan Undang-Undang Tentang Pencegahan dan Pemberantasan Tindak Pidana Pencucian Uang, 2006: 13).

Dalam kaitan ini, Departement of Justice Canada menyebutkan sebagai berikut (Adrian Sutedi, 2008: 237):

1. Aktifitas pencucian uang memungkinkan para penjual dan pengedar narkoba, para penyelundup dan para penjahat lainnya untuk memperluas kegiatan operasinya. Hal ini akan meningkatkan biaya penegakan hukum untuk memberantasnya dan biaya pengobatan dan perawatan serta pengobatan kesehatan bagi para korban atau para pecandu narkoba.

2. Aktifitas pencucian uang mempunyai potensi untuk merongrong masyarakat keuangan (financial community) sebagai akibat dari besarnya jumlah uang yang terlibat dalam kegiatan tersebut. Potensi untuk melakukan korupsi meningkat bersamaan dengan peredaran jumlah uang haram yang sangat besar tersebut.

3. Pencucian uang dapat mengurangi pendapatan pemerintah dari sektor pajak dan secara tidak langsung merugikan para pembayar pajak yang jujur dan mengurangi kesempatan kerja yang sah.

Tindak pidana pencucian uang, biasanya terjadi dalam tindak pidana khusus, seperti korupsi, illegal logging, narkoba dan sebagainya pada dasarnya bermotifkan ekonomi. Tanpa ada kepentingan ekonomi, tindak pidana tersebut tidak akan terjadi. Oleh karena itu, menjadi hal yang cukup penting dalam konteks memupus motivasi seseorang melakukan tindak pidana melalui pendekatan pelacakan, pembekuan, penyitaan dan perampasan aset hasil tindak pidana dari kejahatan yang terorganisir.

Kejahatan terorganisir yaitu any group of individuals whose primary activity involves violating criminal laws to seeks illegal profits and power engaging in racketeering activities and, appropriate, engaging in intricate financial manipulations, (Donald R Cressey, 1969: 319). Di mana dengan sendirinya akan menjadi enggan atau tidak memiliki motivasi untuk melakukan suatu perbuatan pidana apabila hasil perbuatan pidana tersebut dikejar dan dirampas untuk negara. Pendekatan inilah yang sering disebut dengan "strategi pencegahan dan pemberantasan pencucian uang" (antimoney laundering strategy). (Sherman $\mathrm{T}$ dalam Macqueen L (ed), 1993: 12).

Pentingnya membangun rezim anti pencucian uang ini adalah untuk membantu menciptakan stabilitas sistem keuangan karena lembaga keuangan 
dapat terhindar dari berbagai risiko seperti risiko hukum, reputasi, terkonsentrasinya transaksi dan likuiditas, sehingga mampu melaksanakan fungsinya secara efektif pula. Selain itu, pelaksanaan rezim anti pencucian uang tersebut juga diyakini dapat menurunkan angka kriminalitas, karena pelaku tindak pidana tidak lagi memiliki motivasi untuk mengulangi perbuatannya, dan hasil perampasan tindak pidana dapat dimanfaatkan untuk sebesar-besarnya kemakmuran rakyat. Oleh karena itu, pendekatan rezim anti pencucian uang yang dilaksanakan secara efektif, bukanlah suatu hal yang mustahil dilakukan.

Sebaliknya, kegagalan dalam mencegah dan memberantas pencucian uang akan berdampak sangat buruk pada sektor keuangan dan penegakan hukum. Sebagaimana diketahui, bahwa melalui aktifitas pencucian uang, para pelaku kejahatan dapat menyembunyikan asalusul uang atau harta kekayaan dari hasil kejahatan dengan maksud agar mereka dapat menikmati dan menggunakan hasil kejahatan tersebut secara bebas karena uang haram tersebut seolah-olah tampak berasal dari suatu kegiatan yang sah. (Sutan Remy Sjahdeini, 2004: 167-168).

Dalam perkembangannya, modus pencucian uang semakin kompleks dan canggih, bahkan secara universal telah digolongkan sebagai suatu tindak pidana yang biasa disebut white collar crime dan transnational crime. (Harkristuti Harkrisnowo 2004: 2-4). Semakin canggihnya kejahatan pencucian uang, akhirnya mendorong rezim anti pencucian uang untuk merevisi Undang-Undang Nomor 15 tahun 2002 dengan Undang-Undang Nomor 25
Tahun 2003. Semakin dicegah, maka semakin kompleks tindakan kejahatan yang terjadi. Tipologi atau modus-modus TPPU terus berkembang dan cara-cara yang digunakan semakin kompleks dengan melibatkan berbagai lembaga keuangan dan lembaga lainnya yang terkait dengan keuangan.

Banyak pihak yang sependapat bahwa Undang-Undang Pencegahan dan Pemberantasan Tindak Pidana Pencucian Uang lebih efektif untuk memulihkan keuangan negara dalam hal asset recovery, jika dibandingkan dengan UndangUndang Pemberantasan Tindak Pidana Korupsi. Alasannya karena UU TPPU menggunakan paradigma baru dalam penanganan tindak pidana, yaitu dengan pendekatan follow the money untuk mendeteksi TPPU dan tindak pidana lainnya. Selain itu, UU TPPU juga mampu menjerat aktor mafia peradilan.

Sistem peradilan pidana dalam upaya pemberantasan tindak pidana pencucian uang yang dilakukan oleh penegak hukum seperti kepolisian dan kejaksaan, dalam menerapkan UU TPPU ini tentu tidak ada masalah karena mereka memang diberikan mandat yang jelas dalam UU tersebut, namun bagaimana dengan KPK? Dalam Pasal 6 huruf c Undang-Undang Nomor 30 Tahun 2002 tentang Komisi Pemberantasan Korupsi (UU KPK) menyatakan secara tegas dan jelas bahwa KPK mempunyai tugas melakukan penyelidikan, penyidikan, dan penuntutan terhadap tindak pidana korupsi. Pasal 6 ini juga tidak memberikan penjelasan, sehingga dengan demikian kewenangan KPK dalam penyelidikan, penyidikan dan penuntutan 
terbatas hanya terkait dengan tindak pidana Korupsi.

Dalam banyak penanganan kasus korupsi, KPK juga sering mencoba menjerat pelaku menggunakan UU TPPU, dan tidak sedikit yang mengkritik dan memberikan apresiasi atas upaya KPK dalam menyelamatkan keuangan negara. Kritikan ditujukan kepada kewenangan penyidikan dan penuntutan KPK terhadap TPPU. Pada perkara No. 39/Pid.Sus/TPK/2013/PN.Jkt.Pst dengan Terdakwa Ahmad Fathanah, 2 (dua) orang anggota majelis hakim yaitu Joko Subagyo dan I Made Hendra menyatakan dessenting opinion yang menyatakan KPK memang memiliki kewenangan mengusut (menyidik) TPPU, namun pengusutan itu hanya terkait dengan kekayaan yang diketahui atau patut diduga berasal dari Tindak Pidana Korupsi. Tetapi yang berwenang menuntut TPPU adalah Jaksa pada Kejasaan Tinggi atau Kejaksaan Agung, dan Jaksa KPK tidak memiliki hak dalam mengajukan dakwaan dan tuntutan TPPU, karena itu surat dakwaan sepanjang mengenai pencucian uang harus dinyatakan tidak dapat diterima. (http://nasional.kompas.com).

Dalam kasus Anas Urbaningrum juga diwarnai dissenting opinion dari majelis hakim, 2 (dua) anggota majelis hakim yaitu Slamet Subagyo dan Joko Subagyo menilai tim Jaksa KPK tidak berwenang mengajukan perkara pencucian uang ke Pengadilan Tipikor, karena secara eksplisit Undang-Undang Nomor 8 Tahun 2010 Tentang Pencegahan dan Pemberantasan Tindak Pidana Pencucian Uang (UU TPPU), tidak mencantumkan kewenangan KPK untuk menuntut TPPU, sehingga tidak ada landasar yuridis formil KPK dalam menuntut TPPU. (http: //www. globalindo.com/2014/09/24/bedapendapat-vonis-anas-dua-hakim-sebutkpk-tak-berwenang-tuntut-tppu/).

Mudzakir seorang pakar hukum pidana pada Universitas Islam Indonesia (UII) juga berpendapat KPK tidak mempunyai kewenangan untuk menuntut Tindak Pidana Pencucian Uang (http://www.republika.co.id/berita/nasi onal/hukum), karena dalam UU TPPU tidak memberikan kewenangan pada KPK, UU TPPU hanya memberikan lisensi pada KPK untuk melakukan penyidikan, sesuai dengan penjelasan Pasal 74 Yang dimaksud dengan "penyidik tindak pidana asal" adalah pejabat dari instansi yang oleh undang-undang diberi kewenangan untuk melakukan penyidikan, yaitu Kepolisian Negara Republik Indonesia, Kejaksaan, Komisi Pemberantasan Korupsi (KPK), Badan Narkotika Nasional (BNN), serta Direktorat Jenderal Pajak dan Direktorat Jenderal Bea dan Cukai Kementerian Keuangan Republik Indonesia. Penyidik tindak pidana asal dapat melakukan penyidikan tindak pidana Pencucian Uang apabila menemukan bukti permulaan yang cukup terjadinya tindak pidana Pencucian Uang saat melakukan penyidikan tindak pidana asal sesuai kewenangannya. (Penjelasan Pasal 74 UU No. 8 Tahun 2010).

Romli Atmasasmita juga berpendapat KPK tidak memiliki wewenang menuntut TPPU atau tidak ada alas hukum yang kuat KPK untuk menuntut terdakwa korupsi dengan UU TPPU karena penuntut KPK tidak berkoordinasi dan berkonsultasi kepada Jaksa Agung kecuali kepada kelima pimpinan KPK dan kop surat dakwaan atau penuntutan penuntut KPK adalah tercantum "Komisi 
Pemberantasan Korupsi", bukan kejaksaan. (Romli Atmasasmita, Koran Sindo, 17 Januari 2014).

Selain itu penuntut dan penyidik KPK juga diberhentikan sementara dari institusi asalnya selama menjadi penyidik dan penuntut KPK (Pasal 39 ayat (3) UU KPK) sehingga tidak ada hubungan struktural dan hierarkis antara jaksa KPK dan Jaksa Agung. Alasan lainnya sebagaimana diakui Yunus Husein adalah tidak terdapat ketentuan eksplisit yang menyatakan KPK berwenang menuntut TPPU seperti ketentuan Pasal 71 ayat (2) b, Pasal 72 ayat (5) c UU TPPU 2010 yang hanya memberi mandat pada kejaksaan.

Walau banyak ahli yang berbeda pandangan, dan hampir dalam putusan majelis hakim ada yang memberikan pendapat berbeda, namun KPK tetap menggunakan UU TPPU dalam perkara korupsi, dan hampir selalu menerapkan Pasal pencucian uang terhadap Tersangka Korupsi yang kekayaannya melebihi pendapatannya, di antara mereka yang dijerat dengan UU TPPU adalah Nazaruddin, Wa Ode Nurhayati, Lutfhi Hasan Ishaaq, Irjenpol Djoko Susilo, Rubiandini, Anas Urbaningrum dan Akil Mochtar.

\section{METODE PENELITIAN}

Dalam penelitian ini, Penulis menggunakan metode penelitian hukum normatif, yang mencakup tentang asasasas hukum. Selain itu penelitian ini juga mengkaji dan meneliti peraturan perundangundangan. (Soerjono Soekanto, 1986: 15), yakni peraturan perundang-undangan, meta norma yang berasal dari kajian filsafat dan teori hukum. Sehingga ditemukan masalah dan solusi fundamental terkait dengan kewenangan Komisi Pemberantasan Korupsi dalam melakukan penuntutan Money Laundering. Penelitian hukum normatif ini akan bertitik tolak pada bahan pustaka atau data sekunder, dengan cakupan bahan hukum primer, sekunder dan tersier.

Metode penelitian hukum normatif adalah metode atau cara yang dipergunakan di dalam penelitian hukum yang dilakukan dengan cara meneliti bahan pustaka yang ada. (Soerjono Soekanto dan Sri Mamudji, 2009, 13-14). Dengan kata lain penelitian ini penelitian kepustakaan (Library Reseach) artinya penelitian ini dilakukan dengan membaca karya-karya yang relevan dengan objek kajian kemudian memuat kajian tentang penelitian. (Mestika Zed, 2007, 3).

\section{PEMBAHASAN.}

\section{Politik Hukum Undang-Undang Nomor 8 Tahun 2010 Tentang Pencegahan dan Pemberantasan Tindak Pidana Pencucian Uang}

Istilah Money laundering berasal dari Amerika Serikat, istilah ini mempunyai sejarah panjang yang dimulai dari tahun 1930 yang pada waktu itu para pelaku kejahatan yang terorganisir/mafia. (Yunus Husein, 2004: 1). Kelompok kriminal ini melakukan diversifikasi usaha atas hasil kejahatannya dengan cara mengambil alih aktivitas bisnis legal tertentu dengan hasil keuntungan keuangan yang sangat tinggi. (Romli Atmasasmita, 2010: 52).

Money laundering secara populer dapat dijelaskan sebagai aktivitas 
memindahkan, menggunakan atau melakukan perbuatan lainnya atas hasil dari tindak pidana yang kerap dilakukan oleh organized crime maupun individu yang melakukan tindakan korupsi, perdagangan narkotik dan tindak pidana lainnya dengan tujuan menyembunyikan atau mengaburkan asal-usul uang yang berasal dari hasil tindak pidana tersebut sehingga dapat digunakan seolah-olah sebagai uang yang sah tanpa terdeteksi bahwa uang tersebut berasal dari kegiatan illegal, (Yunus Husein, 2003: 26).

Menurut pendapat Barda Nawawi Arief, dapat dikatakan ada 3 (tiga) jenis tindak pidana pencucian uang, yaitu:

1. Mengubah atau memindahkan property yang diketahuinya berasal dari kejahatan, dengan tujuan menyembunyikan asal usul gelap dari property itu atau untuk membantu seseorang menghindari akibat-akibat dari keterlibatannya dalam melakukan kejahatan.

2. Menyembunyikan keadaan sebenarnya dari property yang berasal dari kejahatan itu (baik sumber/ asalusulnya, lokasi, penempatan, pergerakan, penyaluran maupun hakhak yang berhubungan dengan property itu.

3. Menguasai/ menerima, memiliki atau menggunakan propery yang diketahuinya bersal dari kejahatan atau dari keikutsertaannya dalam melakukan kejahatan itu. (Barda Nawawi Arief, 2001, 212-213.)

Undang-undang nomor 8 Tahun 2010 Pasal 1 point (1) menjelaskan yang dimaksud dengan Pencucian Uang adalah segala perbuatan yang memenuhi unsurunsur tindak pidana sesuai dengan ketentuan dalam Undang-Undang ini. Sementara yang dimaksud dengan tindak pidana pencucian uang adalah sebagai berikut : Setiap Orang yang menempatkan, mentransfer, mengalihkan, membelanjakan, membayarkan, menghibahkan, menitipkan, membawa ke luar negeri, mengubah bentuk, menukarkan dengan mata uang atau surat berharga atau perbuatan lain atas Harta Kekayaan yang diketahuinya atau patut diduganya merupakan hasil tindak pidana sebagaimana dimaksud dalam Pasal 2 ayat (1) dengan tujuan menyembunyikan atau menyamarkan asal usul Harta Kekayaan dipidana karena tindak pidana Pencucian Uang dengan pidana penjara paling lama 20 (dua puluh) tahun dan denda paling banyak Rp. 10.000.000.000,00 (sepuluh miliar rupiah).

Money Laundering dewasa ini dinyatakan sebagai bentuk kejahatan perbankan yang merugikan perekonomian bangsa. Kejahatan ini menyangkut pelanggaran di bidang ekonomi dengan memanfaatkan jasa perbankan, keterlibatan perbankan dalam kegiatan pencucian uang dapat berupa (Guy Stessens, 2000: 9).

1. Penyimpanan uang hasil kejahatan dengan nama palsu atau dalam safe deposit box;

2. Penyimpanan uang dalam bentuk deposito/tabungan/giro;

3. Penukaran pecahan uang hasil perbuatan illegal;

4. Pengajuan permohonan kredit dengan jaminan uang yang disimpan pada bank yang bersangkutan;

5. Penggunaan fasilitas transfer atau EFT;

6. Pemalsuan dokumen-dokumen L/C yang bekerjasama dengan oknum pejabat bank terkait; dan

7. Pendirian/pemanfaatan bank gelap.

Kejahatan yang terkait dengan masalah pencucian uang atau Money laundering selama ini belum tersentuh oleh 
kebijakan politik hukum pidana dalam upaya untuk menanggulangi meningkatnya kasus pelanggaran hukum tersebut. Kejahatan ini diangap baru dan sesungguhnya termasuk kedalam extraordinary crime bahkan serious crime karena mempunyai modus operandi yang berneda dan berbahaya dari kejahatan konvensional yang dikenal dalam hukum pidana Indonesia. (Teguh Sulistia dan Aria Zurnetti, 2011, 96).

Hukum pidana sebagai sebuah entitas yang sangat kompleks, meliputi kenyataan kemasyarakatan yang majemuk, mempunyai banyak aspek, dimensi dan fase. (Imam Syaukani dan A. Ahsin Thohari, 2007, 1) Begitu juga fasefase lahirnya ketentuan pidana tentunya tidak terlepas dari politik hukum pada umumnya (Bernard Arief Sidharta, 1999, 116), yakni setiap usaha untuk mewujudkan peraturan yang baik serta sesuai dengan kondisi maupun siuasi tertentu. Begitu juga politik hukum pidana berusaha untuk membuat peraturan perundangundangan pidana yang merujuk pada kondisi dan situasi yang sesuai dan wajar seperti yang diharapkan dan dimaksudkan oleh masyarakat. (Cainur Arrasjid, 2011: 92).

Indonesia pada 17 April 2002 mengundangkan Undang-Undang No. 15 Tahun 2002 Tentang Tindak Pidana Pencucian Uang. Namun oleh FATF, Undang-undang tersebut diminta untuk direvisi karena tidak sesuai dengan rekomendasi Internasional Materi UU No. 15 Tahun 2002 yang dianggap tidak sesuai adalah: pengertian transaksi keuangan mencurigakan yang dianggap kurang luas, adanya batasan lima ratus juta untuk mendefinisikan "hasil kejahatan", tidak adanya ketentuan "anti tiffing of" yang melarang bank atau pejabat tertentu untuk memberitahukan tentang laporan transaksi keuangan mencurigakan yang sedang disusun atau telah dilaporkan, jangka waktu pelaporan transaksi keuangan mencurigakan yang dianggap terlalu lama, yaitu empat belas hari kerja dan tidak adanya ketentuan bantuan hukum timbal balik (mutual legal assistance). (Surat Presiden FATF kepada Menteri Kehakiman dengan tembusan kepada Kepala PPATK a.l. tanggal 8 Juli 2003.) Sehingga pada akhirnya undangundang nomor 15 tahun 2002 dirubah menjadi undang-undang nomor 25 tahun 2003 tentang undang-undang tindak pidana pencucian uang.

Dari sisi eksternal, faktor-faktor pendorong perlunya dilakukan pembaharuan hukum mengenai pencegahan dan pemberantasan TPPU adalah dikeluarkannya revisi rekomendasi Financial Action Task Force on Money Laundering (FATF) sebagai "standard setter" dalam pencegahan dan pemberantasan pencucian uang yang harus diadopsi oleh semua negara, dan adanya perkembangan international best practice. Salah satu dari rekomendasi tersebut, adalah perlunya memperluas lingkup dari pihak pelapor (reporting parties) yang wajib menyampaikan laporan transaksi keuangan mencurigakan (LTKM/STR) kepada lembaga yang berfungsi sebagai Financial Intelligence Unit (FIU) seperti PPATK. Bahkan rekomendasi FATF tersebut tegas menyatakan agar pengacara, notaris atau profesi hukum lainnya dan akuntan serta penyedia barang dan jasa diminta untuk ikut melaporkan LTKM/STR. Kondisi di atas yang mendorong direvisinya UU No. 25 Tahun 2003 menjadi UU No. 8 Tahun 
2010 Tentang Pencegahan dan Pemberantasan Tindak Pidana Pencucian Uang pada tanggal 22 Oktober 2010.

Undang-Undang Nomor 8 Tahun 2010 merupakan perwujudan politik hukum pidana sangat berdayaguna dalam menanggulangi white collar criminal dalam menjalankan aksi kejahatannya terutama saat Indonesia masih mengalami krisis ekonomi. Kehadiran undang-undang ini sangat mendukung penegakkan hukum dalam memelihara dan menjaga stabilitas moneter dan keuangan bangsa dalam hukum pidana, (Teguh Sulistia dan Aria Zurnetti, 2011: 95).

Pencegahan dan pemberantasan tindak pidana Pencucian Uang memerlukan landasan hukum yang kuat untuk menjamin kepastian hukum, efektivitas penegakan hukum, serta penelusuran dan pengembalian harta kekayaan hasil tindak pidana. Pada umumnya pelaku tindak pidana berusaha menyembunyikan atau menyamarkan asal usul Harta Kekayaan yang merupakan hasil dari tindak pidana dengan berbagai cara agar Harta Kekayaan hasil tindak pidananya susah ditelusuri oleh aparat penegak hukum sehingga dengan leluasa memanfaatkan Harta Kekayaan tersebut baik untuk kegiatan yang sah maupun tidak sah.

Karena itu, tindak pidana Pencucian Uang tidak hanya mengancam stabilitas dan integritas sistem perekonomian dan sistem keuangan, tetapi juga dapat membahayakan sendi-sendi kehidupan bermasyarakat, berbangsa, dan bernegara berdasarkan Pancasila dan UndangUndang Dasar Negara Republik Indonesia Tahun 1945.

Dalam konsep anti pencucian uang, pelaku dan hasil tindak pidana dapat diketahui melalui penelusuran untuk selanjutnya hasil tindak pidana tersebut dirampas untuk negara atau dikembalikan kepada yang berhak. Apabila Harta Kekayaan hasil tindak pidana yang dikuasai oleh pelaku atau organisasi kejahatan dapat disita atau dirampas, dengan sendirinya dapat menurunkan tingkat kriminalitas. Untuk itu upaya pencegahan dan pemberantasan tindak pidana Pencucian Uang memerlukan landasan hukum yang kuat untuk menjamin kepastian hukum, efektivitas penegakan hukum serta penelusuran dan pengembalian Harta Kekayaan hasil tindak pidana.

Dalam perkembangannya, tindak pidana Pencucian Uang semakin kompleks, melintasi batas-batas yurisdiksi, dan menggunakan modus yang semakin variatif, memanfaatkan lembaga di luar sistem keuangan, bahkan telah merambah ke berbagai sektor.

Bahwa pencegahan dan pemberantasan tindak pidana Pencucian Uang memerlukan landasan hukum yang kuat untuk menjamin kepastian hukum, efektivitas penegakan hukum, serta penelusuran dan pengembalian Harta Kekayaan hasil tindak pidana, maka DPR RI dan Presiden RI menyusun dan menetapkan UU Nomor 8 tahun 2010 tentang Pencegahan dan Pemberantasan Tindak Pidana Pencucian Uang, (http://acch.kpk.go.id/uu-no8-tahun-2010).

\section{Kewenangan Penuntutan Tindak Pidana Pencucian Uang Menurut Undang- Undang Nomor 8 Tahun 2010}

Dalam sistem hukum acara Indonesia, kewenangan penuntutan diatur dalam Pasal 1 angka 6 Undang-Undang Nomor 8 Tahun 1981 Tentang Hukum Acara Pidana (selanjutnya disebut KUHAP) 
Pasal tersebut menegaskan " Jaksa adalah pejabat yang diberi wewenang oleh undang-undang ini untuk bertindak sebagai penuntut umum serta melaksanakan putusan pengadilan yang telah memperoleh kekuatan hukum tetap". Sedangkan yang dapat bertindak sebagai penuntut umum adalah Jaksa yang diberi wewenang oleh undangundang ini untuk melakukan penuntutan dan melaksanakan penetapan hakim.

Selanjutnya perihal penuntutan ini diatur lebih lanjut dalam Undang-Undang Nomor 16 Tahun 2004 tentang Kejaksaan Republik Indonesia. Pasal 2 UndangUndang ini menegaskan Kejaksaan adalah lembaga pemerintah yang melaksanakan kekuasaan negara di bidang penuntutan serta kewenangan lain berdasarkan undang-undang serta merupakan satu kesatuan yang tidak terpisahkan.

Menurut Undang-Undang Nomor 16 Tahun 2004, Kejaksaan memiliki tugas dan kewenangan meliputi bidang pidana, perdata dan ketentraman umum. Dalam bidang pidana, Kejaksaan memiliki kewenangan: 1). Melakukan penuntutan; 2). Melaksanakan penetapan hakim dan putusan pengadilan yang telah memperoleh kekuatan hukum tetap; 3). Melakukan pengawasan terhadap pelaksanaan putusan pidana bersyarat, putusan pidana pengawasan, dan keputusan lepas bersyarat, melakukan penyelidikan terhadap tindak pidana tertentu berdasarkan undang-undang, dan; 4). Melengkapi berkas perkara tertentu dan untuk itu dapat melakukan pemeriksaan tambahan sebelum dilimpahkan ke pengadilan yang dalam pelaksanaannya dikoordinasikan dengan penyidik.
Secara hukum penuntutan diartikan sebagai tindakan penuntut umum untuk melimpahkan perkara pidana ke pengadilan negeri yang berwenang dalam hal dan menurut cara yang diatur dalam undang-undang ini dengan permintaan supaya diperiksa dan diputus oleh hakim di sidang pengadilan. Sementara penuntut umum bukanlah semua Jaksa yang ada di lembaga Kejaksaan, tetapi jaksa yang diberi wewenang oleh undang-undang ini untuk melakukan penuntutan dan melaksanakan penetapan hakim, (Pasal 1 angka 2 UU No. 16 Tahun 2004).

Jika mengacu pada ketentuan di atas dan berdasarkan asas dominus litis, maka penetapan dan pengendalian kebijakan penuntutan hanya berada di satu tangan yaitu institusi Kejaksaan yang kemudian dilakukan oleh Jaksa yang diangkat dan diberhentikan oleh Kejaksaan Agung.

Selanjutnya, bila dianalisis lebih jauh makna yang terkandung dalam Pasal 2 ayat (3) Undang-Undang No. 16 Tahun 2004, yang menyatakan bahwa kejaksaan sebagaimana dimaksud pada ayat (1) adalah satu dan tidak terpisahkan. Ketentuan ini setidaknya memberikan gambaran bahwa Kejaksaan itu hanya satu dan apabila ia (Jaksa Penuntut Umum) ditugaskan di lembaga lain, maka ia tetap dianggap kejaksaan, karena yang bisa mengangkat dan memberhentikan Jaksa hanyalah Kejaksaan Agung.

Lalu bagaimana dengan kewenangan penuntutan terhadap tindak pidana pencucian uang? Tindak pidana pencucian uang secara umum dapat diartikan sebagai aktivitas memindahkan, menggunakan atau melakukan perbuatan lainnya atas hasil dari tindak pidana yang kerap dilakukan oleh organized crime maupun 
individu yang melakukan tindakan korupsi, perdagangan narkotik dan tindak pidana lainnya dengan tujuan menyembunyikan atau mengaburkan asal-usul uang yang berasal dari hasil tindak pidana tersebut sehingga dapat digunakan seolah-olah sebagai uang yang sah tanpa terdeteksi bahwa uang tersebut berasal dari kegiatan illegal. (Yunus Husein, 26) Undang-Undang-Undang No. 8 Tahun 2010 mengartikan tindak pidana pencucian uang sebagai upaya menempatkan, mentransfer, mengalihkan, membelanjakan, membayarkan, menghibahkan, menitipkan, membawa ke luar negeri, mengubah bentuk, menukarkan dengan mata uang atau surat berharga atau perbuatan lain atas Harta Kekayaan yang diketahuinya atau patut diduganya merupakan hasil tindak pidana sebagaimana dimaksud dalam Pasal 2 ayat (1) dengan tujuan menyembunyikan atau menyamarkan asal usul Harta Kekayaan. Pada bagian ini perlu kita garis bawahi adalah "..harta kekayaan yang diketahui atau patut diduganya merupakan hasil tindak pidana..".

Mengenai penuntutan terkait dengan TPPU dapat dilihat dalam Pasal Pasal 76, yang berbunyi:

(1)Penuntut umum wajib menyerahkan berkas perkara tindak pidana Pencucian Uang kepada pengadilan negeri paling lama 30 (tiga puluh) hari kerja terhitung sejak tanggal diterimanya berkas perkara yang telah dinyatakan lengkap.

(2)Dalam hal penuntut umum telah menyerahkan berkas perkara kepada pengadilan negeri sebagaimana dimaksud pada ayat (1), ketua pengadilan negeri wajib membentuk majelis hakim perkara tersebut paling lama 3 (tiga) hari kerja sejak diterimanya berkas perkara tersebut.

UU TPPU tidak menjelaskan siapa yang dapat melakukan penuntutan terkait dengan TPPU apakah hanya Jaksa Penuntut Umum yang berada di Kejaksaan saja atau bisa dituntut oleh penuntut umum yang berada di lembaga lain. Beranjak dari doktrin lex specialist derogate legi generaly, UU TPPU yang khusus terkait dengan hukum acara merupakan aturan khusus dari KUHAP. Artinya sepanjang tidak diatur oleh UU TPPU, maka ketentuan hukum acara terkait dengan TPPU harus merujuk pada ketentuan KUHAP.

Sebagaimana yang sudah kita bahas di atas, bahwa lembaga negara yang diberikan kewenangan melakukan penuntutan adalah Kejaksaan Republik Indonesia yang dijalankan oleh Jaksa Penuntut Umum yang diangkat dan diberhentikan oleh Jaksa Agung. Sebagaimana kita ketahui, bahwa Penuntut umum yang ada di KPK adalah penuntut umum yang ditugaskan oleh Kejaksaan. Selain itu ada frasa "..harta kekayaan yang diketahui atau patut diduganya merupakan hasil tindak pidana.." di dalam UU TPPU, yang salah satunya merupakan tindak pidana korupsi, dan KPK adalah lembaga yang diberi kewenangan oleh negara melalui Undang-undang Nomor 30 Tahun 2002 untuk melakukan penyelidikan, penyidikan dan penuntutan terhadap tindak pidana korupsi yang dilakukan oleh pejabat negara, aparat penegak hukum dan orang lain yang ada kaitannya dengan tindak pidana korupsi yang dilakukan oleh aparat penegak hukum atau penyelenggara negara.

Sebagaimana yang diketahui beberapa kasus yang telah ditangani oleh KPK itu 
dibarengi tindak pidana asal berupa tindak pidana korupsi dahulunya serta diikuti dengan tindak pidana pencucian uang, di mana fakta-fakta hukum terkait kedua tindak pidana tersebut saling berhubungan dan saling mendukung bahkan dengan tipologi yang terstruktur maka penangannya pun harus dilakukan secara terintegritas. Oleh karena itu, sangat penting untuk menjamin bahwa kewenangan penuntutan tindak pidana pencucian uang yang berasal dari tindak pidana korupsi yang ditangani oleh KPK harus mengikuti kewenangan penuntutan tindak pidana korupsi (sebagai tindak pidana asal) yang dimiliki oleh KPK, ini tentu sejalan dengan prinsip penanganan perkara yang cepat, sederhana, dan biaya ringan serta tercapainya pengembalian keuangan Negara yang optimal serta tidak sesuainya dengan tujuan utama asas diferensiasi fungsional secara instanasional yang mana tidak menimbulkan proses penanganan yang bolak balik untuk menjamin adanya kepastian hokum, (Yahya Harahap, 2010, 49). Cara demikian akan menjadi salah satu jalan sebagaimana kemudian tujuan pembentukan KPK untuk meningkatkan hasil guna upaya pemberantasan korupsi yang dicapai. Jika suatu perkara yang telah ditangani oleh KPK dan dibarengi oleh tindak pidana pencucian uang, jika KPK menyerahkan penuntutan ke kejaksaan Negeri maka tidak efektif dan efisien dalam melakukan penuntutan pemerikasaan di sidang pengadilan dan akan menimbulkan beban, biaya besar dan waktu yang lebih lama.

Sebagaimana yang terdapat dalam pasal 6 UU TPPU maka pengadilan tindak pidana korupsi berdasarkan Pasal 5 berwenang memeriksa, mengadili, dan memutus perkara, tindak pidana korupsi tindak pidana pencucian uang yang tindak pidana asalnya adalah tindak pidana korupsi, dan/atau tindak pidana yang secara tegas dalam undang-undang lain ditentukan sebagai tindak pidana korupsi. Sebagaimana arah kebijakan pemberantasan korupsi, nepotisme, kolusi, mempercepat proses hukum terhadap aparatur pemerintah terutama penegak hukum dan penyelenggara Negara yang diduga melakukan tindak pidana korupsi, kolusi dan nepotisme serta dapat dilakukan tindak administratif untuk mempelancar proses hokum, (Ermansyah Djaja, 2010, 88). Selanjutnya, Tujuan dari hukum itu sendiri adalah keadilan, kemanfaatan, dan kepastian hukum.

Dengan demikian, kewenangan melakukan penuntutan pada perkara tindak pidana pencucian uang yang tindak pidana asalnya adalah tindak pidana korupsi menurut UU TPPU dapat dilakukan oleh Jaksa Penuntut Umum di Kejaksaan dan dapat juga dilakukan oleh Jaksa Penuntut Umum di KPK sepanjang tindak pidana asalnya adalah tindak pidana korupsi yang ditangani oleh KPK. 
Tabel. 1

\section{Putusan Pengadilan}

\begin{tabular}{|c|c|c|c|}
\hline No & Terpidana & $\begin{array}{c}\text { Nomor Perkara \& Pasal yang } \\
\text { didakwakan }\end{array}$ & Putusan \\
\hline 1 & $\begin{array}{l}\text { Luthfi Hasan } \\
\text { Ishaaq }\end{array}$ & $\begin{array}{l}\text { 1. No. } 1995 \mathrm{~K} / \text { Pid.Sus/2014 } \\
\text { 2. Pasal } 12 \text { huruf a Undang-Undang No.31 } \\
\text { Tahun } 1999 \text { tentang Pemberantasan } \\
\text { Tindak Pidana Korupsi sebagaimana telah } \\
\text { diubah dengan Undang-Undang No.20 } \\
\text { Tahun } 2001 \text { tentang Perubahan Atas } \\
\text { Undang-Undang No.31 Tahun } 1999 \\
\text { tentang Pemberantasan Tindak } \\
\text { Pidana Korupsi juncto Pasal } 55 \text { Ayat } \\
\text { 1 ke-1 KUHP. } \\
\text { Pasal } 3 \text { Ayat (1) huruf a, b dan c } \\
\text { Undang-Undang RI No.15 Tahun } \\
\text { 2002 tentang Tindak Pidana } \\
\text { Pencucian Uang sebagaimana telah } \\
\text { diubah dengan Undang-Undang No.25 } \\
\text { Tahun } 2003 \text { tentang Perubahan Atas } \\
\text { Undang-Undang RI No.15 Tahun } \\
2002 \text { tentang Tindak Pidana } \\
\text { Pencucian Uang jo Pasal } 65 \text { ayat (1) } \\
\text { KUHP dan Pasal } 6 \text { ayat (1) huruf b } \\
\text { dan c Undang-Undang RI No.15 } \\
\text { Tahun 2002 tentang Tindak Pidana } \\
\text { Pencucian Uang sebagaimana telah } \\
\text { diubah dengan Undang-Undang } \\
\text { No.25 Tahun } 2003 \text { tentang } \\
\text { Perubahan Atas Undang-Undang RI } \\
\text { No.15 Tahun 2002 tentang Tindak } \\
\text { Pidana Pencucian Uang. } \\
\text { Pasal } 3 \text { Undang-Undang No.8 Tahun } \\
2010 \text { tentang Pencegahan dan } \\
\text { Pemberantasan Tindak Pidana } \\
\text { Pencucian Uang juncto Pasal } 55 \text { Ayat } \\
\text { (1) ke-1 KUHP jo Pasal } 65 \text { Ayat (1) } \\
\text { KUHP, dan Pasal } 5 \text { Undang-Undang } \\
\text { No.8 Tahun } 2010 \text { tentang } \\
\text { Pencegahan dan Pemberantasan } \\
\text { jindak Pidana Pencucian Uang } \\
\text { juncto Pasal } 65 \text { Ayat (1) KUHP, }\end{array}$ & 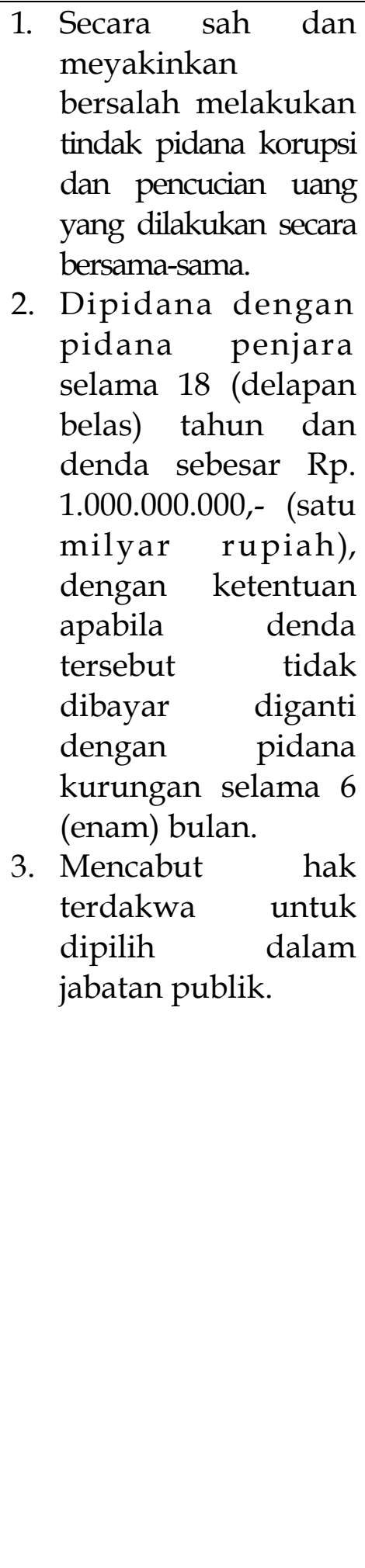 \\
\hline
\end{tabular}




\begin{tabular}{|l|l|}
\hline & Undang-Undang No.48 Tahun 2009, \\
Undang-Undang No.8 Tahun 1981 \\
dan Undang-Undang No.14 Tahun \\
1985 sebagaimana yang telah diubah \\
dengan Undang Undang No.5 Tahun \\
2004 dan perubahan kedua dengan \\
Undang-Undang No.3 Tahun 2009 \\
serta peraturan perundang- \\
undangan lain yang bersangkutan;
\end{tabular}

(Sumber, Direktori Putusan Mahkamah Agung Republik Indonesia)

Tabel. 2

\section{Putusan Pengadilan}

\begin{tabular}{|c|c|c|c|}
\hline No & Terpidana & $\begin{array}{c}\text { Nomor Perkara \& Pasal yang } \\
\text { didakwakan }\end{array}$ & Putusan \\
\hline 1 & $\begin{array}{l}\text { Wa Ode } \\
\text { Nurhayati }\end{array}$ & $\begin{array}{l}\text { 1. No. 214PK/Pid.Sus/2014 } \\
\text { 2. Pasal } 12 \text { huruf a Undang-undang } \\
\text { No. } 31 \text { Tahun } 1999 \text { tentang } \\
\text { Pemberantasan Tindak Pidana } \\
\text { Korupsi sebagaimana telah diubah } \\
\text { dengan Undang-undang No. } 20 \\
\text { Tahun } 2001 \text { tentang Perubahan Atas } \\
\text { Undang-undang No. } 31 \text { Tahun } 1999 \\
\text { tentang Pemberantasan Tindak } \\
\text { Pidana Korupsi. } \\
\text { Pasal } 3 \text { Undang-undang Nomor } 8 \\
\text { Tahun } 2010 \text { tentang Pencegahan dan } \\
\text { Pemberantasan Tindak Pidana } \\
\text { Pencucian Uang jo Pasal } 65 \text { ayat (1) } \\
\text { KUHP, serta Undang-undang No. } 8 \\
\text { Tahun 1981 tentang Kitab Undang- } \\
\text { undang Hukum Acara Pidana } \\
\text { (KUHAP) serta ketentuan-ketentuan } \\
\text { peraturan perundang-undangan dan } \\
\text { hukum yang berkenaan dengan } \\
\text { perkara ini. }\end{array}$ & 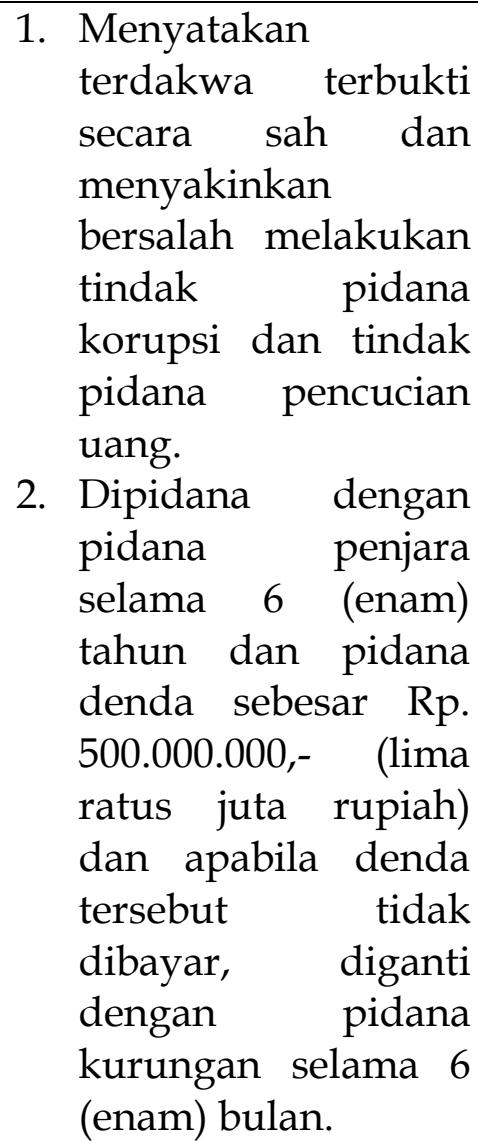 \\
\hline
\end{tabular}

(Sumber, Direktori Putusan Mahkamah Agung Republik Indonesia) 


\section{Kewenangan Komisi Pemberantasan Korupsi Dalam Melakukan Penuntutan Terhadap Tindak Pidana Pencucian Uang}

Dalam beberapa tahun terakhir, KPK semakin gencar menerapkan pasal pencucian uang dalam perkara korupsi. KPK hampir selalu menerapkan pasal pencucian uang terhadap tersangka korupsi yang kekayaannya jauh melampaui pendapatannya. Mereka antara lain mantan Presiden PKS Lutfhi Hasan Ishaaq, mantan Kepala SKK Migas Rudi Rubiandini, dan mantan Ketua MK M Akil Mochtar. Hal itu dilakukan karena penerapan pasal pencucian uang terhadap tersangka korupsi akan menimbulkan efek jera sehingga pemberantasan korupsi jadi lebih efektif. (Indonesia Legal Rountable, http:/ / www.ilr.or.id/2014/08/pengguna an-pasal-pencucian-uang-naik/).

Sebelum menjawab apakah Jaksa Penuntut Umum pada KPK berwenang melakukan penuntutan dalam tindak pidana pencucian uang, terlebih dahulu perlu kita membahas mengenai kewenangan itu sendiri. Dalam hukum tata negara, kewenangan diartikan sebagai kekuasaan yang sah/ legitimate. Kata kewenangan dalam bahasa Inggris disebut juga dengan authority dan dalam bahasa Belanda disebut dengan bovedegheid.

Disebut dengan kekuasaan yang sah karena undang-undang yang memberikan kewenangan tersebut, dengan kata lain tidak ada kewenangan tanpa undangundang yang mengaturnya. Dalam asas hukum dikenal dengan asas legalitas.

Dengan demikian, munculnya kewenangan adalah membatasi agar penyelenggara negara dalam melaksanakan pemerintahan dapat dibatasi kewenangannya agar tidak berlaku sewenang-wenang.
Kemudian muncul pula asas dalam hukum administrasi negara "tidak ada kewenangan tanpa pertanggungjawaban." Oleh karena itu siapapun atau pejabat manapun harus mempertanggung jawabkan setiap tugas dan kewenangannya.

Maka, untuk mengetahui lebih lanjut dari pada siapa yang mesti bertanggung jawab dari pejabat tersebut maka hal ini penting untuk diuraikan tiga cara memperoleh wewenang:

1. Atribusi adalah pemberian kewenangan pemerintahan oleh pembuat undang-undang kepada organ pemerintahan tersebut. Artinya kewenangan itu bersifat melekat terhadap pejabat yang dituju atas jabatan yang diembannya. Misalnya berdasarkan Pasal 41 UU Nomor 27 Tahun 2009 tentang MD3 menegaskan "DPR dapat membentuk undang-undang untuk disetuji bersama dengan Presiden".

2. Delegasi adalah pelimpahan kewenangan pemerintahan dari organ pemerintahan yang satu kepada organ pemerintahan lainnya. Atau dengan kata lain terjadi pelimpahan kewenangan. Jadi tanggung jawab/ tanggung gugat berada pada penerima delegasi atau delegataris. Misalnya: pemerintah pusat memberi delegasi kepada semua Pemda untuk membuat Perda (termasuk membuat besluit/ keputusan) berdasarkan daerahnya masing-masing.

3. Mandat terjadi jika organ pemerintahan mengizinkan kewenangannya dijalankan oleh organ lain atas namanya. Pada mandat tidak terjadi peralihan tanggung jawab, melainkan tanggung jawab tetap melekat pada sipemberi mandat. Misalnya instruksi gubernur kepada sekretaris daerah agar ia bertanda tangan untuk keputusan 
pencairan anggaran pendidikan. Jadi di sini jika jika keputusan yang hendak digugat berarti tetap yang digugat/ sebagai tergugat adalah Gubernur.

Terkait dengan Penuntutan, di dalam hukum acara Indonesia setidaknya terdapat 3 (tiga) aturan yang mengatur, yaitu KUHAP, Undang-Undang Kejaksaan dan Undang-Undang Komisi Pemberantasan Korupsi. Di dalam KUHAP dijelaskan bahwa Penuntut Umum adalah Jaksa yang diberi wewenang oleh Undang-Undang untuk melakukan penuntutan. Selanjutnya pada Pasal 2 ayat (1) UU No. 16 Tahun 2004 tentang Kejaksaan RI menegaskan bahwa kejaksaan adalah lembaga pemerintahan yang melaksanakan kekuasaan negara di bidang penuntutan serta kewenangan lain berdasarkan undang-undang. Pada Pasal 2 ayat (3) UU Kejaksaan menegaskan bawah Kejaksaan sebagaimana dimaksud pada ayat (1) adalah satu dan tidak dipisahkan.

Terkait dengan KPK sendiri, ia dibentuk sesuai dengan ketentuan Pasal 43 UU 31 Tahun 1999 Tentang Pemberantasan Tindak Pidana Korupsi sebagaimana telah diubah dengan UU No. 20 tahun 2001 tentang perubahan atas UU No. 31 Tahun 1999 dengan tugas dan wewenang melakukan pemberantasan tindak pidana korupsi. Jika mengacu pada ketentuan di atas, maka kewenangan KPK hanya dalam hal pemberantasan korupsi. Selanjutnya jika lebih jauh kita melihat ketentuan Pasal 1 ayat (1) UU No. 30 Tahun 2002 jo Pasal 4 UU No. 30 Tahun 2002 jo Pasal 6 poin c UU No. 30 Tahun 2002 jo Pasal 38 ayat (1) dan (2) UU No. 30 Tahun 2002 jo Pasal 39 ayat (1) UU No. 30 Tahun 2002, dapat dilihat bahwa KPK dibentuk untuk menangani Tindak Pidana Korupsi mulai dari Penyelidikan, Penyidikan, maupun Penuntutan.

Berbicara mengenai penuntutan dalam perkara TPPU, maka tidak bisa dilepaskan dari penyidikan. Pasal 74 UU TPPU menyatakan "Penyidikan tindak pidana Pencucian Uang dilakukan oleh penyidik tindak pidana asal sesuai dengan ketentuan hukum acara dan ketentuan peraturan perundang-undangan, kecuali ditentukan lain menurut UndangUndang ini." Berdasarkan ketentuan di atas, maka KPK sebagai penyidik tindak pidana asal, proses pengusutan harta dan kekayaan yang diduga berasal Tindak Pidana Korupsi membutuhkan pengetahuan dan pemahaman yang utuh untuk menyelidiki sumber uang, proses transaksi, pelaku yang terlibat serta dalam menentukan kerugian keuangan Negara dan pelaku sebenarnya, maka berdasarkan Pasal 75 UU TPPU tertulis proses penyidikan Tindak Pidana Pencucian Uang dan tindak pidana asal dalam hal ini Tindak Pidana Korupsi dapat digabungkan.

Penggabungan penyidikan antara Tindak Pidana Pencucian Uang dengan Tindak Pidana Korupsi harus sistematis dan sinergi dengan penyidikan dan penuntutan yang dilakukan oleh Komisi Pemberantasan Korupsi, karena esensi adalah proses pemeriksaan dan pengusutan harta dan kekayaan dari pelaku kejahatan agar optimal, apabila penyidikan dan penuntutan dalam Tindak Pidana Pencucian Uang tersebut dapat dilakukan Komisi Pemberantasan Korupsi secara sistematis, maka proses penuntutan Tindak Pidana Pencucian Uang dalam sidang pengadilan lebih berkualitas dan 
pengusutan harta kekayaan yang akan disita guna mengembalikan kerugian keuangan dan perekonomian Negara dapat dilakukan secara benar dan pasti.

Tindak pidana pencucian uang, dikategorikan sebagai tindak khusus, sehingga penanganannya tidak cukup dilakukan dengan penanganan biasa seperti penanganan kejahatan konvensional pada umumnya. Apabila wewenang Komisi Pemberantasan Korupsi pada penanganan Tindak Pidana Pencucian Uang hanya terbatas pada penyidikan yang hanya membuat berkas acara pemeriksaan kemudian diserahkan kepada Jaksa penuntut umum, maka proses seperti ini justru memperumit dan dapat menimbulkan celah hukum, sedangkan sisi lain Tindak Pidana Pencucian Uang yang berasal dari Tindak Pidana Korupsi harus segera ditangani guna menentukan pelaku dan jumlah kerugian keuangan Negara. Proses penanganan Tindak Pidana Pencucian Uang yang berasal dari Tindak Pidana Korupsi yang rumit tersebut dapat dilihat dari penjelasan berikut:

1. Penyidik menyerahkan berkas perkara kepada penuntut umum (Pasal 8, Pasal 14 huruf a dan Pasal 110 ayat (1) KUHAP)

2. Penuntut umum memberikan perpanjangan penahanan atas permintaan penyidik (Pasal 14 huruf c dan Pasal 24 ayat (2) KUHAP)

3. Dalam hal penuntut umum berpendapat hasil penyidikan belum lengkap, ia segera mengembalikan kepada penyidik disertai petunjuknya dan penyidik wajib melengkapinya dengan melaksanakan penyidikan tambahan (Pasal 14 huruf $b$ dan Pasal 110 ayat (2) dan ayat (3) KUHAP)
4. Dalam hal penyidik mulai melakukan penyidikan/pemeriksaan, memberitahukan hal kepada penuntut umum (Pasal 109 ayat (1) KUHAP).

5. Dalam hal penyidikan menghentikan penyidikan, pemberitahuan hal itu kepada penuntut umum (Pasal 109 ayat (2) KUHAP), Sebaliknya dalam hal penuntut umum menghentikan penuntutan ia memberitahukan turunan surat ketetapan kepada penyidik (Pasal 140 ayat (2) huruf c KUHAP).

6. Penuntut umum memberitahukan turunan surat pelimpahan perkara, surat dakwaan kepada penyidik (Pasal 143 ayat (4) KUHAP), demikian pula dalam hal penuntut umum mengubah surat dakwaan ia memberikan turunan perubahan surat dakwaan kepada penyidik (Pasal 144 ayat (3) KUHAP), (Chaerudin, dkk, 2008, 123).

Jika langkah-langkah di atas harus dilakukan, maka proses peradilan dalam TPPU yang tindak pidana asalnya adalah tindak pidana korupsi akan berjalan sangat lama dan tidak efektif. Beranjak dari doktrin lex specialist, UU TPPU khususnya berkaitan dengan ketentuan hukum acara merupakan aturan khusus dari KUHAP yang berlaku saat ini. Artinya sepanjang tidak ditentukan secara khusus oleh UU TPPU, semua hukum acara pidana terkait dengan perkara TPPU masih merujuk pada ketentuan KUHAP. Pasal 1 Angka 7 KUHAP menyebutkan Penuntutan adalah "tindakan penuntut umum untuk melimpahkan perkara pidana ke pengadilan negeri yang berwenang dalam hal dan menurut cara yang diatur dalam undangundang ini dengan permintaan supaya diperiksa dan diputus oleh hakim di sidang pengadilan". Sementara penuntut uтum adalah jaksa yang diberi wewenang oleh 
undang-undang ini untuk melakukan penuntutan dan melaksanakan penetapan hakim.

Berdasarkan hal di atas, muncul pemahaman bahwa tugas penuntutan merupakan kewenangan khusus yang dimiliki oleh institusi kejaksaan yang kemudian dilakukan oleh Jaksa yang diangka dan diberhentikan oleh Jaksa Agung. Tidak hanya itu, sebelum memangku jabatan sebagai Jaksa, terlebih dahulu harus disumpah dihadapan Jaksa Agung, yang menandakan seseorang baru dianggap sah dan memiliki kewenangan sebagai penuntut umum.

Selama ini, kewenangan penuntutan yang ada di institusi KPK tidak lain dan tidak bukan merupakan kewenangan yang dilakukan oleh Jaksa yang ditugaskan atau di-BKO-kan (Bawah Kendali Operasi) oleh Institusi Kejaksaan RI (ia diangkat, disumpah dan diberhentikan oleh Jaksa Agung) untuk melakukan penuntutan perkara-perkara korupsi di KPK. Sebagai institusi yang bertugas menyelenggarakan penyelidikan, penyidikan dan penuntutan kasus-kasus korupsi, maka KPK memiliki landasan yang kuat untuk melakukan penuntutan tindak pidana pencucian uang, selagi dan selama tindak pidana pencucian uang yang tindak pidana asalnya adalah tindak pidana korupsi.

Dalam kajian kewenangan, maka pada proses penuntutan TPPU yang dilakukan oleh Jaksa Penuntut Umum pada KPK, melekat kewenangan atribusi, karena Jaksa Penuntut Umum pada KPK adalah Jaksa yang dilantik, disumpah dan ditugaskan oleh Institusi Kejaksaan untuk melakukan penuntutan di KPK.
Jika berkaca dari putusan pengadilan tipikor atas dakwaan Jaksa Penuntut Umum pada KPK yang menggabungkan pidana asal berupa tindak pidana korupsi dengan tindak pidana pencucian uang atas beberapa terdakwa yang dinyatakan bersalah, maka hal ini semakin mempertegas bahwa KPK memang mempunyai wewenang melakukan penuntutan terhadap tindak pidana pencucian uang yang tindak pidana asalnya adalah tindak pidana korupsi.

\section{PENUTUP}

\section{Kesimpulan}

1. Pencegahan dan pemberantasan tindak pidana Pencucian Uang memerlukan landasan hukum yang kuat untuk menjamin kepastian hukum, efektivitas penegakan hukum, serta penelusuran dan pengembalian Harta Kekayaan hasil tindak pidana. Maka usaha untuk mewujudkan peraturan yang baik serta sesuai dengan kondisi maupun siuasi tertentu, politik hukum pidana berusaha untuk membuat peraturan perundang-undangan pidana yakni UU No 8 Tahun 2010 sebagai ius constitutum dalam pencegahan dan pemberantasan tindak pidana pencucian uang.

2. Kewenangan melakukan penuntutan pada perkara tindak pidana pencucian uang yang tindak pidana asalnya adalah tindak pidana korupsi menurut undang-undang nomor 8 tahun 2010 dapat dilakukan oleh Jaksa Penuntut Umum Pada Kejaksaan dan jaksa Penuntut Umum pada KPK, apabila tindak pidana asalnya adalah tindak 
pidana korupsi yang ditangani oleh KPK.

3. Ketentuan Pasal 76 ayat (1) UU TPPU harus dimaknai bahwa penuntut umum sebagai satu kesatuan, sehingga apakah penuntut umum yang bertugas di Kejaksaan Agung RI atau yang bertugas di KPK adalah sama, dengan demikian penuntut umum KPK berwenang melakukan penuntutan pada kasus tindak pidana pencucian uang yang tindak pidana asalnya +

Untuk menghentikan perdebatan kewenangan KPK dalam melakukan penuntutan perkara tindak pidana pencucian uang sebagaimana yang diatur oleh UU No. 8 tahun 2010 tentang tindak pidana pencucian uang, maka perlu merevisi ketentuan penjelasan pasal 76 dengan menyebutkan bahwa Penuntut umum di KPK mempunyai kewenangan melakukan penuntutan terhadapa tindak pidana pencucian uang jika tindak pidana asalnya adalah tindak pidana korupsi yang ditangani oleh KPK.

\section{DAFTAR KEPUSTAKAAN}

\section{Buku}

Adrian Sutedi, 2008, Tindak Pidana Pencucian Uang, Bandung, Citra Aditya Bakti

Barda Nawawi Arief, 2001, Masalah Penehakan Hukum \& Kebijakan Penanggulangan Kejahatan, Bandung, Citra Aditya Bakti

Bernard Arief Sidharta, 1999, Refleksi Tentang Struktur Ilmu Hukum; Sebuah Penelitian Tentang Fondasi Kefilsafatan dan Filsafat Keilmuan Ilmu Hukum Sebagai Landasan Pengembangan Ilmu
Hukum Nasional Indonesia, Bandung, Mandar Maju

Cainur Arrasjid, 2011, Hukum Pidana Perbankan, Jakarta, Sinar Grafika

Chaerudin, dkk, 2008, Strategi Pencegahan dan Penegakan Hukum Tindak Pidana Korupsi, Bandung, Refika Adhitama

Donald R Cressey, 1969, The Theft of the Nation: The Strcture and Operation of Organized Crime in America, New York: Harper and Row

Ermansyah Djaja, 2010, Meredesain Pengadilan Tindak Pidana Korupsi, Jakarta, Sinar Garfika

Guy Stessens, 2000, Money Laundering: A New International Law Enforcement Model, Cambridge University Press, First Published

Imam Syaukani dan A. Ahsin Thohari, 2007, Dasar-Dasar Politik Hukum, Jakarta, PT. Raja Grafindo Persada.

Mestika Zed, 2007, Metode Penelitian Kepustakaan, Jakarta, Yayasan Obo, Indonesia

Romli Atmasasmita, 2010, Globalisasi dan Kejahatan Bisnis, Jakarta, Kencana

Sutan Remy Sjahdeini, 2004, Seluk-Beluk Tindak Pidana Pencucian Uang dan Pembiyaan Terorisme, Jakarta: PT Pustaka Utama Grafiti

Sherman T, 1993, International Efforts to Combat Money Laundering: The Role of the Financial Task Force", dalam MacQueen L (ed.), Money Laundering, Edinburgh

Soerjono Soekanto, 1986, Pengantar Penelitian Hukum, Jakarta, UI Press 
dan Sri Mamudji, 2009, Penelitian

Hukum NormatifSuatu Tinjauan

Singkat, Cetakan ke - 11. Jakarta, PT

Raja Grafindo Persada

Teguh Sulistia dan Aria Zurnetti, 2011, Hukum Pidana Horizn Baru Pasca Reformasi, Jakarta, Raja Grafindo Persada

Yahya Harahap, 2010, Pembahasan Permasalahan Dan Penerapan KUHAP, Jakarta, Sinar Grafika.

\section{Jurnal dan Karya Ilmiah}

Harkristuti Harkrisnowo, 2004, Kriminalisasi Pencucian Uang (Money Laundering), Makalah Disampaikan pada Video Conference Nasional yang diselenggarakan oleh PPATK, BI, UI, UGM, USU, UNDIP, UNAIR, dan ELIPS di Jakarta

Yunus Husein, 2004, Tindak Pidana Pencucian Uang (Monye Laundering) Dalam Perspektif Hukum Internasional, Jurnal Hukum International (Indonesian Journal of International Law Vol. 1 No. 2) Faculty of Law University of Indonesia

Yunus Husein, 2003, PPATK: Tugas, Wewenang, dan Peranannya Dalam Memberantas Tindak Pidana Pencucuian Uang, Jurnal Hukum Bisnis, Volume 22 No.3, 2.

Romli Atmasasmita, Artikel "KPK Tidak Berwenang Menuntut TPPU", Koran Sindo, 17 Januari 2014.

\section{Undang-Undang}

Undang-Undang Nomor 30 Tahun 2002 Tentang Komisi Pemberantasan Tindak Pidana Korupsi
Undang-Undang Nomor 15 Tahun 2002 tentang Tindak Pidana Pencucian Uang

Undang-Undang Nomor 25 Tahun 2003 Tentang Tindak Pidana Pencucian Uang

Undang-Undang Nomor 8 Tahun 2010 tentang Pencegahan dan Pemberantasan Tindak Pidana Pencucian Uang

Naskah Akademik Rancangan UndangUndang Tentang Pencegahan dan Pemberantasan Tindak Pidana Pencucian Uang, Jakarta, 2006.

\section{Website}

http://nasional.kompas.com/read/2013/ 11/04/2101274/Vonis.Fathanah.2ki m.Beda.Pendapat diakses pada tanggal 23 Maret 2015 jam 12.00 Wib

http://www.globalindo.co/2014/09/24/ beda-pendapat-vonis-anas-duahakim-sebut-kpk-tak-berwenangtuntut-tppu/diakses pada tanggal 23 Maret 2015 jam 12.05 WIB

http:/ / www.republika.co.id/berita/nasio nal/hukum/13/11/21/mwm5tdpakar-hukum-kpk-tak-berwenangtuntut-tppu diakses pada tanggal 23 Maret 2015 jam $11.35 \mathrm{Wib}$

http:/ /acch.kpk.go.id/uu-no-8-tahun2010, Dikases pada 15 Maret 2015 pukul 21.36

Indonesia Legal Rountable, http://www.ilr.or.id/2014/08/peng gunaan-pasal-pencucian-uang-naik/ diakses pada tanggal 24 Maret 2015 jam 20.00 Wib. 